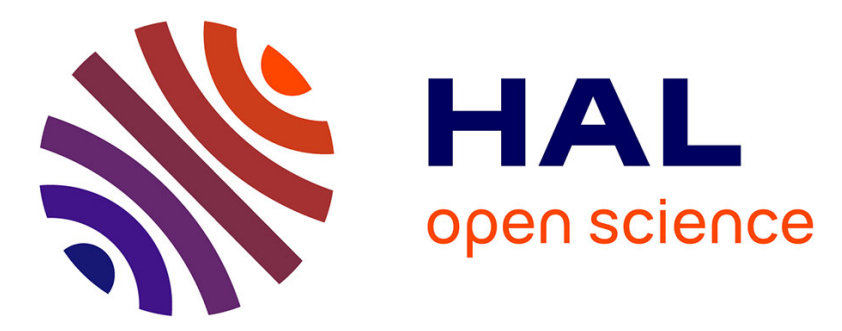

\title{
Control strategy of Hybrid sources for Transport applications using supercapacitors and batteries
}

\author{
Mamadou Baïlo Camara, H. Gualous, F. Gustin, A. Berthon
}

\section{To cite this version:}

Mamadou Baïlo Camara, H. Gualous, F. Gustin, A. Berthon. Control strategy of Hybrid sources for Transport applications using supercapacitors and batteries. 2006 CES/IEEE 5th International Power Electronics and Motion Control Conference, Aug 2006, Shanghai, China. pp.1-5, 10.1109/IPEMC.2006.4778037 . hal-03005783

\section{HAL Id: hal-03005783 \\ https://hal.science/hal-03005783}

Submitted on 14 Nov 2020

HAL is a multi-disciplinary open access archive for the deposit and dissemination of scientific research documents, whether they are published or not. The documents may come from teaching and research institutions in France or abroad, or from public or private research centers.
L'archive ouverte pluridisciplinaire HAL, est destinée au dépôt et à la diffusion de documents scientifiques de niveau recherche, publiés ou non, émanant des établissements d'enseignement et de recherche français ou étrangers, des laboratoires publics ou privés. 


\title{
Control strategy of Hybrid sources for Transport applications using supercapacitors and batteries
}

\author{
M.B. Camara, H. Gualous, F. Gustin, A. Berthon \\ L2ES Laboratory, University of Franche-Comte \\ Rue Thierry Mieg, F90010 BELFORT, FRANCE \\ mamadou.camara@utbm.fr
}

\begin{abstract}
In this article, the authors propose an approach to the problem of the power management in transport applications. The mobile experimental platform ECCE is a series hybrid vehicle which currently has three sources of energy: two thermal machines each coupled with an alternator and a lead-acid battery pack of nominal voltage $540 \mathrm{~V}$. The alternators are inter-connected with the DC-link by means of the rectifiers. Our contribution is focused on studying the energy coupling between this battery pack and that of supercapacitors in order to find the best compromise between dimensions of the electric power devices, the efficiency mobile energy storing devices, the energy exchanges, and the capacity of exchange of electric power. The supercapacitors module consists of a pack of 108 cells and can supply a maximum of $270 \mathrm{~V}$. The main objective is to be able to provide a power of $216 \mathrm{~kW}$ by supercapacitor module to the DC-link for 20 seconds.
\end{abstract}

Keywords- Hybrid vehicle, Supercapacitors, Buck-Boost, Control strategy, Energy storage, multi source system

\section{INTRODUCTION}

The energy requirements in transport applications are increasing day by day. The developments in the field of power electronics and command have made it possible to increase the performances of traction devices. However the limitations in the case of single source vehicles are due to batteries which till present are the principle source of energy. The various type batteries of traction used until now cannot satisfy the future energy requirements of the transport applications. The batteries are designed to supply power requirement in the transition period. The high valves of energy in the transition state severely affect the battery life. The battery manufacturers are not very optimistic on the fast evolution of de capacities and performances of the batteries of traction; it is therefore interesting to make the hybridization of the source, to rely less on battery during the transition phases. Among the various possible technological solutions (Supercapacitors, flywheels) for the hybrid sources, we are interested in that using of supercapacitors. But, for the

Supercapacitors to follow the energy needs of the future applications of transport and find their place with or in replacement of the batteries, it is necessary that the productions of these devices of strong power are at reasonable cost. Software (SABER) is used for simulation and a data acquisition system with a microcontroller (PIC18F4431) is setup. The general structure of the hybrid system is represented by Figure1.

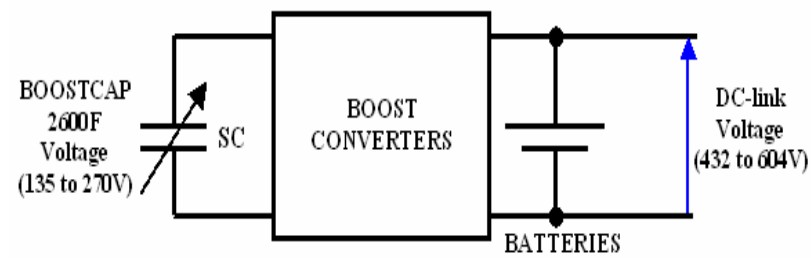

Figure1. General structure of hybrid system

\section{MODELING AND COMMAND BY INVERSE BOOST MODEL}

\section{A. Converter topology}

In this configuration, a boost converter will control the energy exchange between the packs of battery and supercapacitors as indicated in the Figure 2. The system consists of a power source (supercapacitors), a source of energy (battery), a load representing traction vehicle and a boost type converter $[1,4,6]$.

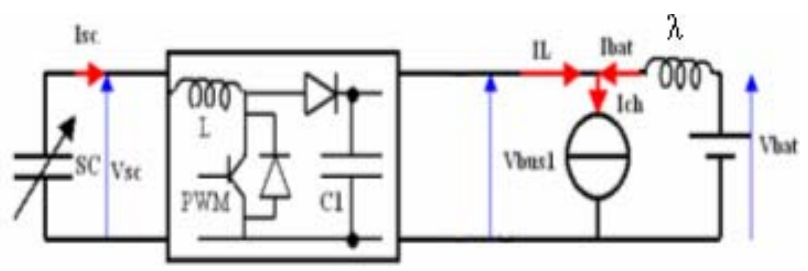

Figure2. Simple structure of the boost converter

\section{B. Modeling of boost converter}

Suppose that the semi-conductors are simple switches, the dynamic model of supercapacitors can be represented by equations (1).

$$
\left\{\begin{array}{l}
\frac{d}{d t}\left(i_{\text {sc }}\right)=\frac{V_{\text {sc }}-(1-\alpha) \cdot V_{\text {bus } 1}}{L} \\
\frac{d}{d t}\left(i_{\text {bat }}\right)=\frac{V_{\text {bat }}-V_{\text {bus } 1}}{\lambda} \\
i_{c}=C \cdot \frac{d}{d t}\left(V_{\text {bus } 1}\right) \\
I_{\text {ch }}=I_{L}+I_{\text {bat }}
\end{array}\right.
$$




\section{Control by inverse boost model}

The control law can be represented by equation (2).

$$
\alpha=1-\frac{\mathrm{V}_{\mathrm{sc}}-\mathrm{V}_{\mathrm{L}}}{\mathrm{V}_{\mathrm{bat}}-\mathrm{V}_{\lambda}} \approx 1-\frac{\mathrm{I}_{\mathrm{L}}}{\mathrm{I}_{\mathrm{sc}}}
$$

This voltage is compared with a triangular signal having $1 \mathrm{~V}$ amplitude (Umax) with frequency of IGBT of $10 \mathrm{kHz}$ to generate PWM signal.

The references of current for supercapacitors are obtained from power assessments between the pack and DC-link.

$$
I_{\text {scref }}=\frac{V_{\text {bus } 1}}{\eta \cdot V_{\text {sc }}} \cdot\left(I_{\text {ch }}-I_{\text {batref }}\right)=\frac{V_{\text {bus } 1}}{\eta \cdot V_{\text {sc }}} \cdot I_{\text {Lref }}
$$

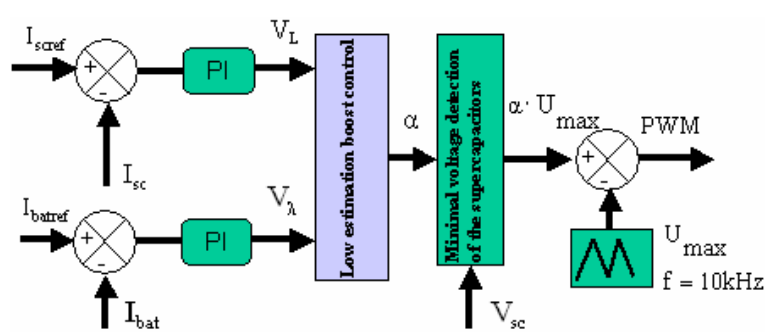

Figure3. Control strategy of the boost converter

where $\eta$ is the efficiency of the boost converter

\section{MODELING AND CONTROL OF PARALLEL BOOSTS}

\section{A. Converter topology}

To avoid overloads with only one boost converter a parallel structure has been proposed, to satisfy the energy request of the hybrid electric vehicle during transient states $[2,3,5]$. This topology is shown on Figure4.

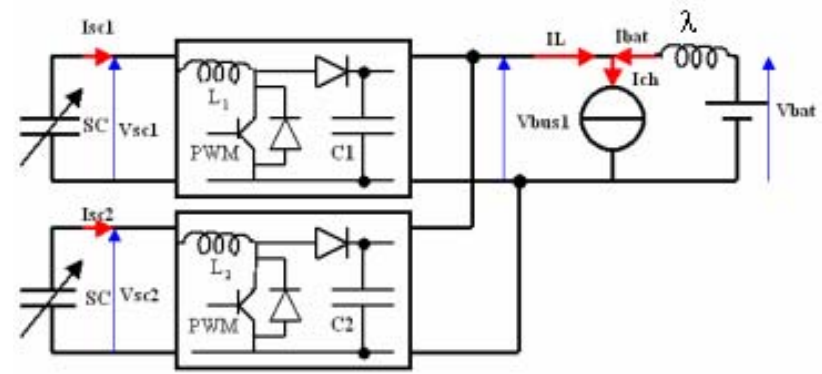

Figure4. Parallel topology of boost converters

The system consists of two sources of power (supercapacitors), a source of energy (batteries), an active load which represents vehicle traction system and two boost converters which ensures the energy exchange between the sources and the DC-bus.

\section{B. Modeling boost converters}

The model for parallel boost structure for current regulation can be represented by differential equations (4), where $I_{c h}$ and $I_{L}$ are active load and DC-link current respectively.

$$
\left\{\begin{array}{l}
\mathrm{I}_{\mathrm{ch}}=\mathrm{I}_{\mathrm{L}}+\mathrm{I}_{\text {bat }} \\
\frac{\mathrm{d}}{\mathrm{dt}}\left(\mathrm{i}_{\mathrm{sc} 1}\right)=\frac{\mathrm{V}_{\mathrm{sc} 1}-(1-\alpha) \cdot \mathrm{V}_{\text {bus } 1}}{\mathrm{~L}_{1}} \\
\frac{\mathrm{d}}{\mathrm{dt}}\left(\mathrm{i}_{\mathrm{sc} 2}\right)=\frac{\mathrm{V}_{\mathrm{sc} 2}-(1-\alpha) \cdot \mathrm{V}_{\text {bus } 1}}{\mathrm{~L}_{2}} \\
\frac{\mathrm{d}}{\mathrm{dt}}\left(\mathrm{i}_{\text {bat }}\right)=\frac{\mathrm{V}_{\text {bat }}-\mathrm{V}_{\text {bus } 1}}{\lambda} \\
\mathrm{i}_{\mathrm{c}}=\mathrm{C}_{1} \cdot \frac{\mathrm{d}}{\mathrm{dt}}\left(\mathrm{V}_{\text {bus } 1}\right)=\mathrm{C}_{2} \cdot \frac{\mathrm{d}}{\mathrm{dt}}\left(\mathrm{V}_{\text {bus } 1}\right)
\end{array}\right.
$$

\section{Application of control by inverse boost model}

Two regulation methods have been investigated. The first method consists in controlling independently the voltage drops across inductors. The control law established for this purpose is given by the expression (5)

$$
\alpha=1+\frac{1}{2} \cdot \frac{\left(\mathrm{V}_{\mathrm{L} 1}-\mathrm{V}_{\mathrm{sc} 1}\right)+\left(\mathrm{V}_{\mathrm{L} 2}-\mathrm{V}_{\mathrm{sc} 2}\right)}{\mathrm{V}_{\mathrm{bat}}-\mathrm{V}_{\lambda}}
$$

The drawback of this method is the significant number of parameters which should be optimized to control the battery current.

The second method consists in controlling the sum the voltage drops across the inductances. The control law which generates modulating signal of the PWM is given by (6).

$$
\alpha=1+\frac{1}{2} \cdot \frac{\left(\mathrm{V}_{\mathrm{L} 1}+\mathrm{V}_{\mathrm{L} 2}\right)-\left(\mathrm{V}_{\mathrm{sc} 1}+\mathrm{V}_{\mathrm{sc} 2}\right)}{\mathrm{V}_{\mathrm{bat}}-\mathrm{V}_{\lambda}}
$$

The advantage of this method compared to the first is in the reduction of the number of parameters to be optimized to control the battery current.

\section{MODELING AND CONTROL OF PARALLEL BOOST STRUCTURES WITH PARALLEL SOURCES}

To reduce the weight of the vehicle a parallel structure has been proposed which enables to decrease the number of smoothing inductors for supercapacitors currents. The topology of this structure of boosts is indicated on the Figure5.

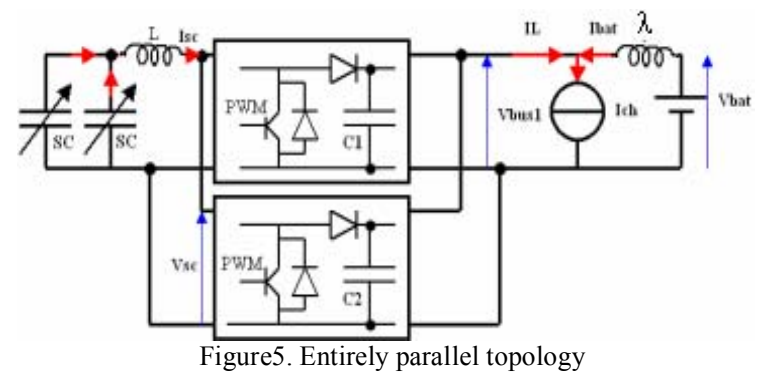




$$
\left\{\begin{array}{l}
\mathrm{V}_{\mathrm{sc} 1}=\mathrm{V}_{\mathrm{sc} 2}=\mathrm{L} \cdot \frac{\mathrm{d}}{\mathrm{dt}}\left(\mathrm{i}_{\mathrm{sc}}\right)+(1-\alpha) \cdot \mathrm{V}_{\text {bus } 1} \\
\mathrm{~V}_{\text {bus } 1}=\mathrm{V}_{\text {bat }}-1 \cdot \frac{\mathrm{d}}{\mathrm{dt}}\left(\mathrm{i}_{\text {bat }}\right) \\
\mathrm{i}_{\mathrm{c}}=\mathrm{C}_{1} \cdot \frac{\mathrm{d}}{\mathrm{dt}}\left(\mathrm{V}_{\text {bus } 1}\right)=\mathrm{C}_{2} \cdot \frac{\mathrm{d}}{\mathrm{dt}}\left(\mathrm{V}_{\text {bus } 1}\right) \\
\mathrm{I}_{\mathrm{ch}}=\mathrm{I}_{\mathrm{L}}+\mathrm{I}_{\text {bat }}
\end{array}\right.
$$

The control strategy of this structure is same as applied to the first one.

\section{SiMULATION RESULTS}

Some results of simulations of various structures will be presented. The common objective is to provide to the DC-link a power of $216 \mathrm{~kW}$ during 20 seconds or $400 \mathrm{~A}$ under a voltage ranging between $432 \mathrm{~V}$ and $604 \mathrm{~V}$. We fixed the reference of battery current at 100A.

\section{A. Simple structure of the boost converter}

From 0 to 0.5 second and 10.5 to 11 seconds the reference of battery current is equal to the current requested by the active load. In these intervals of time the boost converter is switched off. It can be noted that the control makes it possible to keep of battery current (Ibat) around 100A except at the moment of change of the active load current. These peaks of current which appear are caused by the delay of the control of the current loops. Because of the fast discharge of supercapacitors, an overlapping loop of supercapacitor current has been used, so that the reduction of the supercapacitor voltage (Vsc) is compensated by the supercapacitors current (Isc) increase.
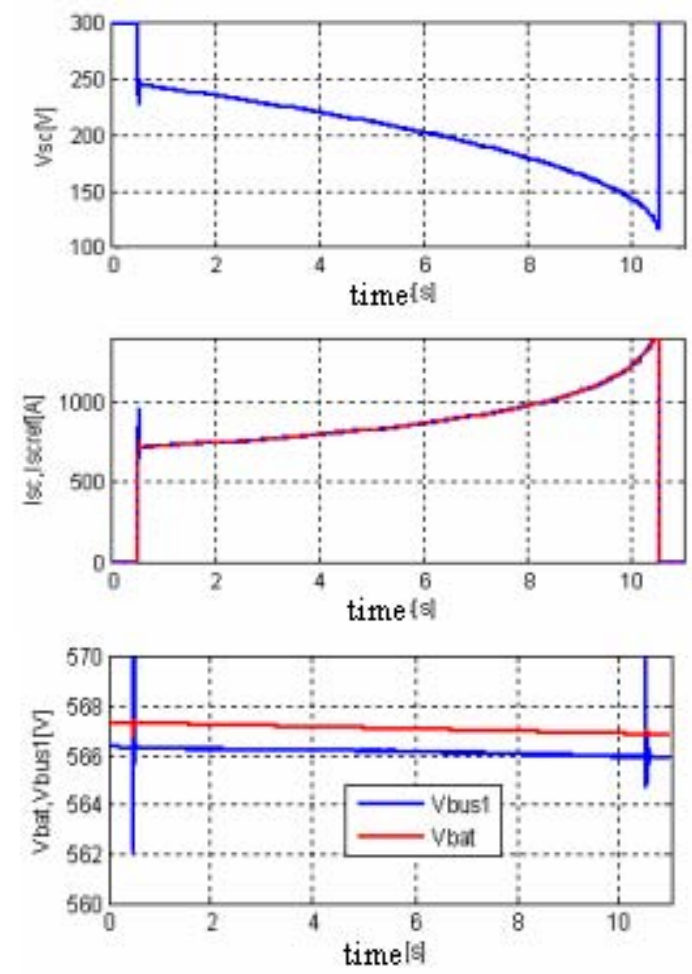

Figure6. Supercapacitors and batteries current and voltages.
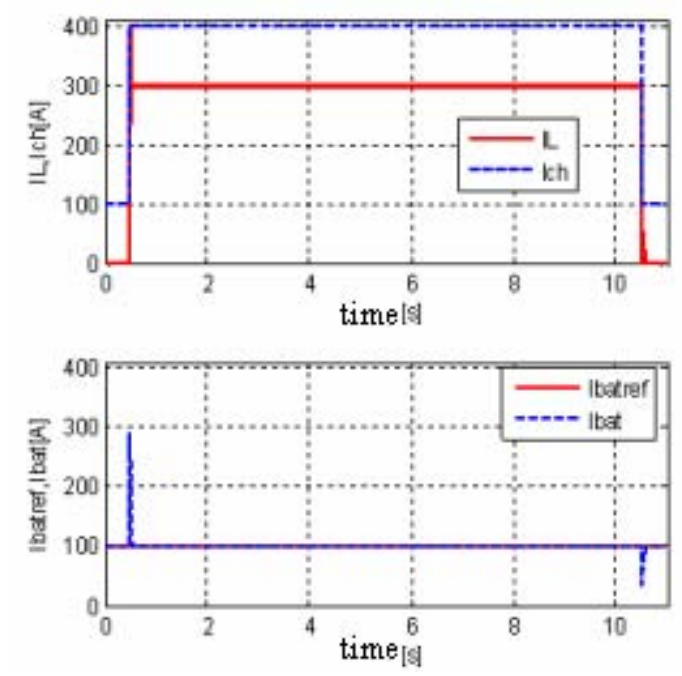

Figure7. Percentage contribution of supercapacitors and batteries

\section{B. Parallel structure of boost converters}

To check the control of the boost converters, the reference of battery current (Ibatref) is fixed at 100A and active load current is set to (Ich) 400, 200 and 400A respectively. The control of the boost converter is satisfactory except around 0.5 second and 1 second when the current loops do not have necessary time to act. The currents (Isc1) and (Isc2) output respectively by the pack1 and the pack2 are same. The voltages of two modules of supercapacitors (Vsc1, Vsc2) are same.
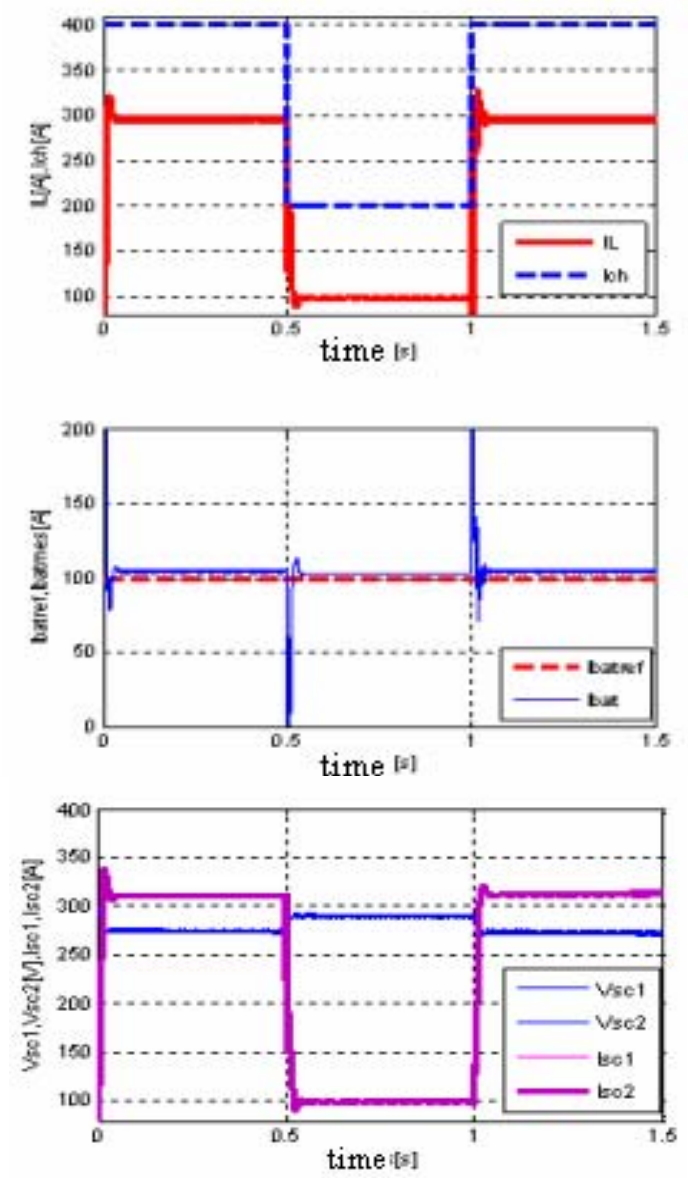

Figure8. Results for (Ich=400A-200A-400A) and Ibatref=100A 


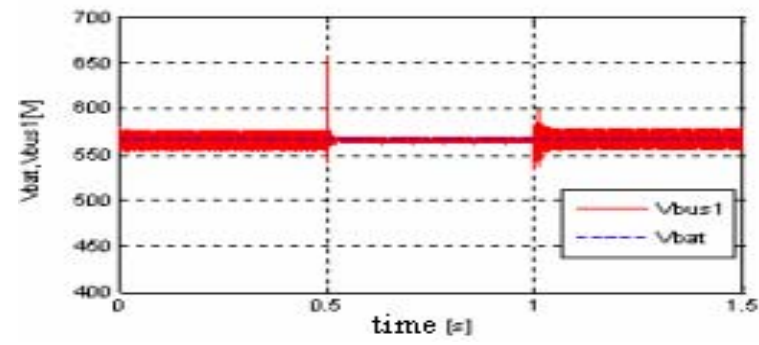

Figure9. DC-link and batteries voltages.

The reference battery current (Ibatref) always remains within 100A. Between 0-0.5 second and 20.5-22 seconds the converters are with blocked off and in the interval (0.5-20.5 seconds) $75 \%$ of current requested by the load is output by both supercapacitor packs (IL). After 20.5 seconds of discharge the control of battery current (Ibat) becomes almost impossible. The distribution of the powers is equal between the supercapacitor packs; this is why the voltage and current output by both packs are identical ( $\mathrm{Vsc} 1=\mathrm{Vsc} 2$ and $\mathrm{Isc} 1=\mathrm{Isc} 2)$.
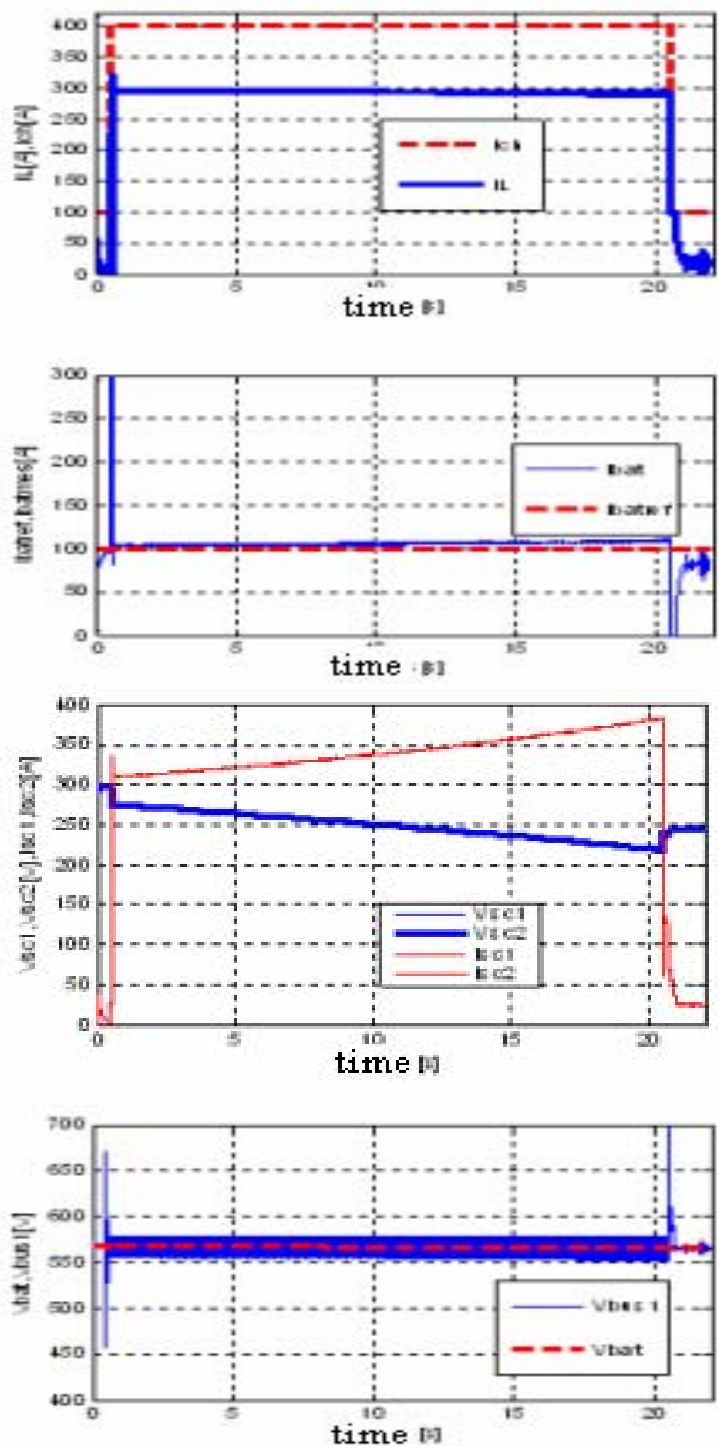

Figure10. Results for $(\mathrm{Ich}=100 \mathrm{~A}-400 \mathrm{~A}-100 \mathrm{~A})$ and Ibatref=100A

\section{Entirely parallel structure}

The simulation conditions are identical to the parallel structure. The peaks of battery current around 0.5 second and 20.5 seconds are due to the commutation of load current (Ich).
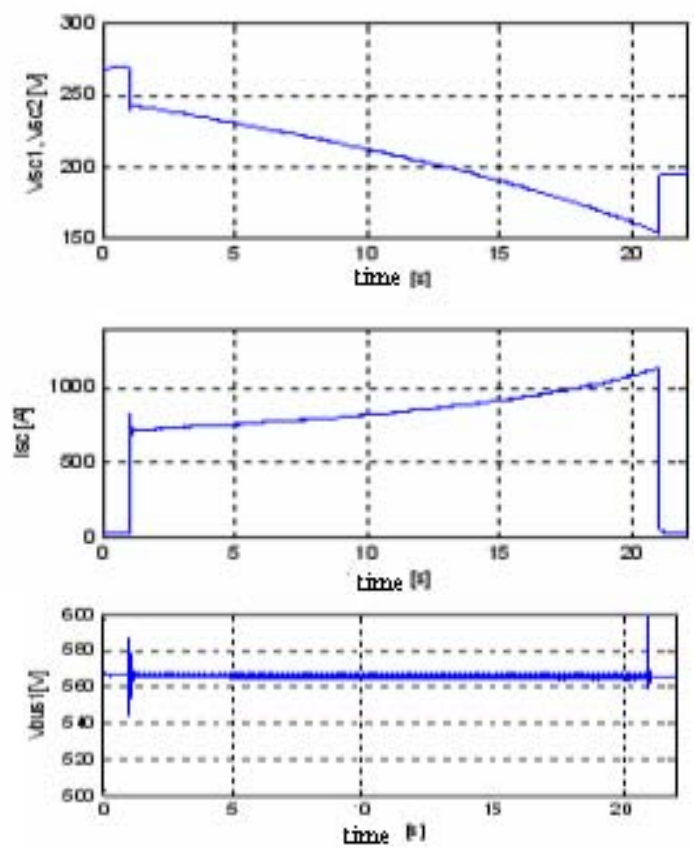

Figure11. Supercapacitors and DC-link current and voltages.
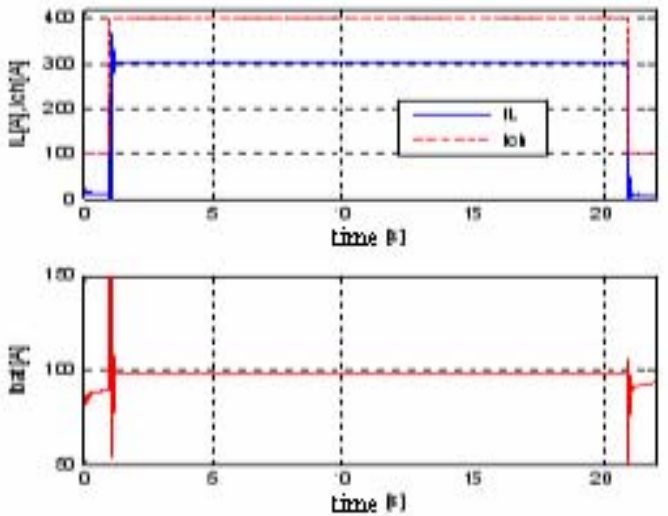

Figure12. Percentage contribution of supercapacitors and batteries

\section{DESIGN AND EXPERIMENTAL RESULTS}

A reduced size experimental testbench has been designed. It includes a pack of supercapacitors made up of 11 cells of $2600 \mathrm{~F}$ each with a maximum voltage of $2.5 \mathrm{~V}$, a pack of batteries of 4 elements of $12 \mathrm{~V}$ with a capacity of $92 \mathrm{Ah}$, a boost converter, a filtering capacitor of $6.8 \mathrm{mF}$, inductors for smoothing supercapacitor and battery currents of values $50 \mu \mathrm{H}$ and $25 \mu \mathrm{H}$ respectively. The control of the system is ensured by a microcontroller of the type PIC18F4431 which presents 9 analog inputs and 8 PWM outputs. 


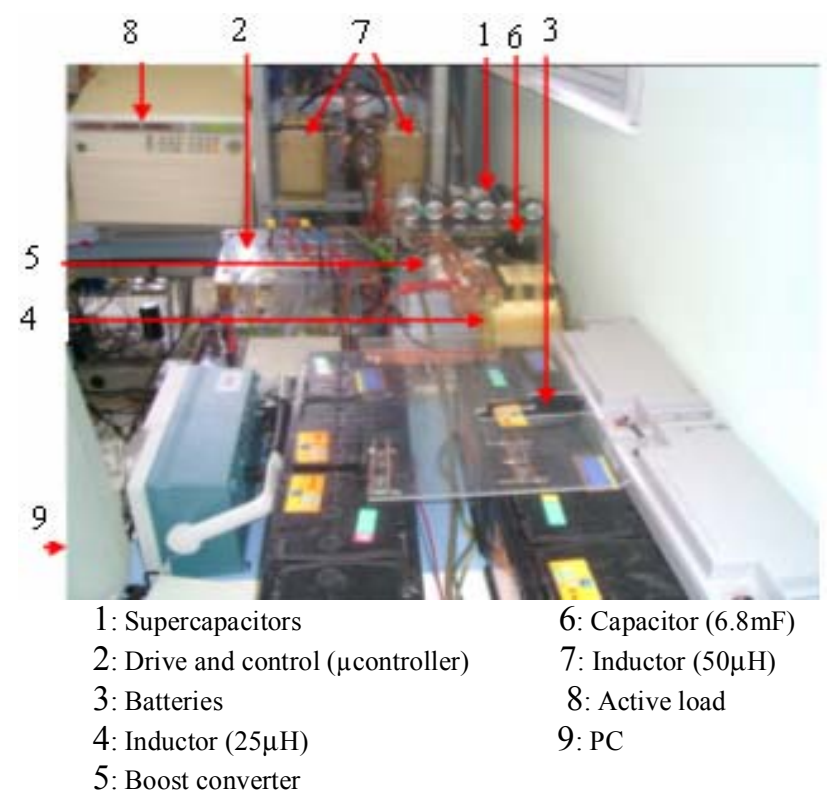

Figure13. Realisation of simple structure of the boost converter

\section{B. Experimental results}

The current supplied by supercapacitor pack to the continuous bus (Ilref) is fixed at 20A. The current of the load is fixed at 25A. The powers (Pbus) and (Pch) are obtained respectively by the product of the currents measured (IL and Ich) by the measured DC-link voltage and that of the battery by its current and measured voltage. The efficiency of the converter is defined by the ratio of the power of the continuous bus by that of supercapacitors. We notice that the efficiency according to the current output by the supercapacitors decreases. This is explained by the fact that, the progressive discharge of the supercapacitor pack is compensated by a progressive increase in its current; which results in higher losses by Joule effect.
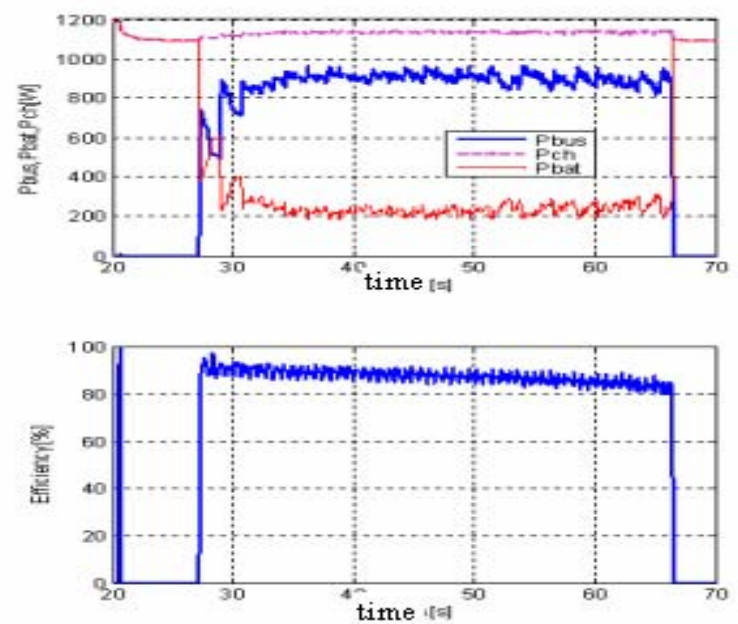

Figure14. Powers and efficiency of boost converter

\section{CONCLUSION}

In this article, we have presented the modeling of various possible structures of multi source system of energy and the associated strategies of control. To control the total system, we have established laws for boost converters with a reference of battery current of $100 \mathrm{~A}$. The references for supercapacitors are calculated by the strategy of energy management for the vehicle. The current supplied by battery follows the reference value except in the transition region where load current varies from 100 to $400 \mathrm{~A}$ and 400 to $100 \mathrm{~A}$. For reasons of simplicity and cost, the simple structure of the boost converter is most interesting but unfortunately is far from the DC-link power requested by the vehicle $(216 \mathrm{~kW})$ during 20 seconds. To avoid the DC-link ageing of supercapacitors, we proposed the parallel structure of boost converters. What seems satisfactory for the energy requested of the hybrid electric vehicle in 20 seconds. This structure presents some disadvantages in particular the cost is higher and the weight is more significant contrary to the simple structure of the boost converter. To reduce the weight of the vehicle we proposed the parallel structure which enables us to decrease the number of smoothing inductances of supercapacitors current. The control allows to maintain battery current around the desired value $(100 \mathrm{~A})$ in spite of the significant request for power on the DC-link.

\section{ACKNOWLEDGMENT}

This work is under the continuity of the work started within laboratory L2ES within the program framework ECCE in collaboration with Electronic and Electrical engineering Research Center of BELFORT (CREEBEL).

\section{REFERENCES}

[1] L.Solero, L. Lidozzi, J-A. Pomilio, Design of Multiple-Input Power converter for Hybrid Vehicles, IEEE Trans. On power Electronics, vol:20, Nº5, September 2005

[2] P. Mestre, S.Astier, Utilization of Ultracapacitors as auxiliary power source in Electric Vehicle, EPE ,vol:4, pp4670-4673, Sept.1997

[3] A. Di Napoli, F.Crescimbini, L. Solero, F. Caricchi, F.G. Capponi, Multiple-Input DC-DC power for power-flow management in hybrid vehicles, IEEE,vol.3,pp1578-1585,oct 2002

[4] B. Michael, B.Burnett, L.J. Borle, A power system combining batteries and supercapacitors in a solar/hydrogen hybrid electric vehicle, IEEE,vol:3, Sept. 2005

[5] M. Marchesoni, C. Vacca, A New DC-DC Converter Structure for Power Flow Management in Fuel-Cell Electric Vehicles with Energy Storage Systems, $200435^{\text {th }}$ Annual IEEE Conf. Power Electronics Specialists, Germany

[6] P.Thounthong,S.Raël,B.Davat, Control strategy of fuel cell/supercapacitors hybrid power sources for electric vehicle, Journal of Power Sources September 2005 